\title{
A DESJUDICIALIZAÇÃO E A TECNOLOGIA EM BUSCA DA EFETIVIDADE NA EXECUÇÃO CIVIL ${ }^{1}$
}

\section{DEJUDICIALIZATION AND TECHNOLOGY, AIMING EFFECTIVITY IN CIVIL PROCEDURE ENFORCEMENT}

Rodrigo Frantz Becker Doutorando em Direito Processual Civil pela UERJ. Mestre em Direito pela UnB. Advogado da União. Consultor Jurídico do Governo do Distrito Federal. Ex-Procurador-Geral da União. Ex-Diretor da Escola Superior de Advocacia da OAB/DF. Professor da Graduação e da Pós-Graduação do IDP em Brasília e Goiânia. Membro-fundador e Presidente da ABPC (Associação Brasiliense de Direito Processual Civil). Membro do IBDP (Instituto Brasileiro de Direito Processual). Brasília/DF. E-mail: beckerprocessocivil@gmail.com.

Renan Lima Barão Servidor do Tribunal de Justiça do Distrito Federal, lotado no Gabinete da $1^{\text {a }}$ Vice-Presidência. Compõe a equipe técnica do Centro de Inteligência da Justiça do Distrito Federal. ExAssessor Jurídico no Ministério Público Federal. Pósgraduado em Direito Processual Civil pela UCAM. Brasília/DF. E-mail: renanbarão@gmail.com.

RESUMO: O artigo pretende analisar a efetividade da execução no direito processual brasileiro, com objetivo de se buscar compreender se o processo executivo consegue atingir a finalidade para a qual se propõe. Para tanto, por meio de uma pesquisa bibliográfica e documental realiza uma análise descritiva do problema da efetividade do processo de execução e examina tanto soluções tecnológicas como o projeto de desjudicialização da

\footnotetext{
${ }^{1}$ Artigo recebido em 25/04/2021 e aprovado em 20/07/2021.
} 
execução, como medidas para se perseguir tal efetividade no Brasil, demonstrando como tais caminhos podem realmente levar a uma busca mais eficaz pelo adequado adimplemento da obrigação.

PALAVRAS-CHAVE: Processo civil. Execução. Efetividade. Desjudicialização. Soluções tecnológicas.

ABSTRACT: The article intends to analyze the effectiveness of enforcement in Brazilian civil procedural law, with the aim of seeking to understand whether the executive process can achieve the goal for which it is proposed. Therefore, through a bibliographic and documentary research, it performs a descriptive analysis of the problem of the effectiveness of the judicial enforcement. Likewise, it examines both technological solutions and the project to dejudicialize judicial enforcement, as measures to make it more effective in Brazil, demonstrating how such paths can actually lead to a more effective search for the proper fulfillment of the obligation.

KEYWORDS: Civil Procedure. Judicial enforcement. Effectiveness. Dejudicialization. Technologic solutions.

\section{Introdução}

A efetividade da execução é tratada por alguns doutrinadores como princípio ${ }^{2}$. De fato, ela pode ser analisada dessa forma, ou ainda, como um elemento essencial e informador da execução ${ }^{3}$. Está-se diante, talvez, da maior preocupação do processualista moderno, verdadeiramente comprometido com um processo civil de resultados. Trata-se de corolário da garantia do acesso à justiça (art. $5^{\circ}$, inciso XXXV, da CF) e pode ser conferida também a partir da leitura do princípio da eficiência (art. 37 da CF), dos princípios da duração razoável do processo e da celeridade (art. $5^{\circ}$, inciso LXXVIII, da CF), e da garantia do devido

\footnotetext{
${ }^{2}$ A ideia de efetividade do processo ganha contornos ainda mais fortes na fase de execução.

${ }^{3}$ Aqui se usa a palavra "execução" em sentido amplo, para definir tanto o cumprimento de sentença como a execução de título extrajudicial.
} 
processo legal (art. $5^{\circ}$, incisos LIV e LV, da CF). Nesse sentido, tem razão a doutrina que caracteriza a tutela jurisdicional adequada e efetiva como um direito fundamental ${ }^{4}$.

O processo, portanto, deve dar tudo aquilo e exatamente aquilo que o titular do direito material tenha direito de conseguir. Alguns doutrinadores falam na necessidade do exato adimplemento ou de se ter uma execução específica ${ }^{5}$ para dar a verdadeira concretude que a efetividade deve ter na execução.

E isso se aplica aos dois tipos de procedimentos executivos existentes no Brasil: cumprimento de sentença e execução de título extrajudicial. O primeiro considerado um prolongamento do processo de conhecimento, até mesmo uma fase deste processo, enquanto o segundo, uma nova ação, com todos os consectários advindo desse enquadramento, relativos à teoria da ação propriamente dita. Tanto um quanto o outro padecem do mesmo problema de efetividade.

Fato é que a execução vem sendo reestruturada. Tanto é que recentemente foi apresentado projeto de lei que visa desjudicializá-la (PL 6204/2019), deixando grande parte do procedimento executivo para o âmbito extrajudicial.

Ao mesmo tempo, o Poder Judiciário tem buscado desenvolver e aperfeiçoar mecanismos de gestão, desburocratização e otimização dos atos processuais, especialmente com a utilização de novas ferramentas tecnológicas que prometem vencer os obstáculos da fase executiva, com o intuito de torná-la mais efetiva.

Pretende-se, neste artigo, examinar alguns aspectos da execução, sem deixar, por certo, de pensar se o modelo hoje concebido no Brasil é realmente efetivo, a fazer com o que o processo executivo consiga atingir a finalidade para a qual se propõe.

Para tal desiderato, buscar-se-á na doutrina a base para a montagem do terreno acadêmico acerca da efetividade do processo executivo, enquanto normativos diversos, em vigor, funcionarão como alicerces para demonstrar como tal efetividade hoje é perseguida com soluções tecnológicas. A pesquisa ainda terá por base projeto de lei que busca, na desjudicialização da execução, um resultado mais efetivo do processo executivo brasileiro.

\footnotetext{
${ }^{4}$ MARINONI, L. G.; ARENHART, S. C.; MITIDIERO, D. Manual de processo civil. 5a . ed. São Paulo: Thomson Reuters Brasil, 2020.

${ }^{5}$ FUX, Luiz. A reforma do processo civil: comentários e análise crítica da reforma infraconstitucional do Poder Judiciário e da Reforma do CPC, $2^{a}$ edição. Niterói: Impetus, 2008, p. 88.
} 
Tanto a pesquisa doutrinária como a legislativa serão o norte, assim, para a revisão bibliográfica e documental com o objetivo de realizar uma análise descritiva do problema posto em debate: a efetividade do processo de execução. Tal pesquisa servirá também para uma possível resolução do problema, a partir do exame das soluções tecnológicas e da retirada do processo executivo, ao menos em parte, da competência do Poder Judiciário.

Desse modo, a partir de um exame dos aspectos da efetividade do processo executivo e do atual estágio em que ela se encontra no processo civil brasileiro, pretende-se encontrar possíveis alternativas para um melhor desempenho da execução. Tal análise levará em conta, por certo, os mecanismos atuais, sobretudo tecnológicos, à disposição dos operadores do direito, sem deixar de lado as perspectivas para uma maior efetividade, com a concretização da desjudicialização do processo de execução no Brasil.

\section{A efetividade da execução no processo civil moderno}

Nos termos do art. 797 do CPC $^{6}$, a execução faz-se no interesse do credor e deve garantir-lhe o mesmo resultado que seria obtido caso o devedor cumprisse espontaneamente a obrigação (execução específica). A conversão em pecúnia, existente nas obrigações de fazer e não fazer, deve ser sempre considerada como uma hipótese excepcional (art. 499 do CPC), pois o credor não pode ser instado a receber prestação diversa daquela prevista no título, muito embora, ainda nesse caso, considere-se que a execução foi efetiva.

Assim é que o Poder Judiciário deve procurar sempre entregar exatamente aquilo que se foi buscar, ou seja, conceder a entrega específica do bem da vida almejado. Por exemplo, se a parte requerer o pagamento de quantia baseado em confissão de dívida, o Estado-juiz deverá entregar exatamente o pagamento pleiteado, mesmo que seja convertendo a venda de bens feita judicialmente para dinheiro, porque aí estará satisfazendo aquilo que foi buscado judicialmente pelo jurisdicionado. ${ }^{7}$

\footnotetext{
${ }^{6}$ Art. 797. Ressalvado o caso de insolvência do devedor, em que tem lugar o concurso universal, realiza-se a execução no interesse do exequente que adquire, pela penhora, o direito de preferência sobre os bens penhorados.

${ }^{7}$ RICHTER, Bianca Mendes Pereira; SILVA, Natalia Diniz da. O controle de convencionalidade como limite para a discricionariedade do juiz na execução: análise das decisões recentes que têm aplicado o artigo 139, IV, do novo Código de Processo Civil. In: MAIA, M. L.; LIRA; Y. (org.). Controle de Convencionalidade Temas aprofundados. Salvador: Juspodivm, 2018.
} 
Ainda que não tenha sido direcionada especificamente à execução, a ideia acima desenvolvida é aplicável indistintamente a tal tipo de processo, na medida em que se busca nele, em primeiro lugar, conceder "fisicamente" aquilo que lhe foi requerido, seja por título judicial, seja por título extrajudicial, de modo a satisfazer (efetivar) o direito a ele conferido.

Nesse sentido, Cândido Dinamarco destaca que o ideal atingível através da execução é a produção dos mesmos efeitos que produziria a satisfação voluntária do direito pelo próprio obrigado ou por terceiro, ou seja, a realização da vontade da lei em seu resultado econômico objetivo ${ }^{8}$.

Por isso que, na execução, o Estado-juiz busca todos os meios de conceder, da mesma forma como disposto no título, o bem da vida conferido ao credor: dinheiro, um fazer, um não fazer ou mesmo a entrega de uma coisa. Assim agindo, ele garante que a execução tenha sido efetiva.

Em termos práticos, se a obrigação deixou de ser voluntariamente cumprida, o credor disporá de outro direito (a ação de conhecimento ou de execução), cujo exercício provocará o emprego da coação por parte do órgão jurisdicional competente (consequência da execução).

Com vistas ao atingimento desse resultado efetivo, o ordenamento jurídico confere ao Estado o poder de lançar mão de meios de sub-rogação e coerção, que compõem aquilo que se costuma referir como meios executivos ${ }^{9}$.

Os meios de sub-rogação são aqueles em que o Estado legitimamente invade a esfera de interesses do devedor e arvora para si a realização de atos voltados à produção do resultado prático perseguido, como ocorre, por exemplo, na prática de apreensão e expropriação de bens do executado.

Os meios de coerção, por sua vez, consistem na aplicação de mecanismos de estímulo ao cumprimento da obrigação, atuando não sobre o patrimônio do devedor, mas sobre sua vontade, a exemplo da fixação de imposição de multa cominatória para o cumprimento de certa decisão judicial ${ }^{10}$.

\footnotetext{
${ }^{8}$ DINAMARCO, Cândido Rangel. Execução Civil. $5^{a}$. ed. São Paulo: Malheiros editores, 1997, p. 110.

${ }^{9}$ CHIOVENDA, Giuseppe. Instituições de Direito Processual Civil. Vol. I, $3^{\text {a }}$ edição. São Paulo: Saraiva, 1969, p. 288.

${ }^{10}$ CAMARA, Alexandre Freitas. Execução civil e temas afins do CPC/1973 ao novo CPC: estudos em homenagem ao professor Araken de Assis. São Paulo: Revista dos Tribunais, 2014
} 
Vale pontuar que é justamente em razão da busca pela efetividade do processo que se autoriza ao juiz a adoção de meios coercitivos atípicos (art. 139, inciso IV, do CPC/2015), conferindo-lhe a liberdade de aplicar outros mecanismos executivos não expressos em leis, hábeis a forçar o cumprimento da obrigação pelo devedor quando os meios típicos não forem suficientes.

Exige-se, para tanto, a observância aos postulados da razoabilidade e da proporcionalidade, "sempre com o objetivo de conferir ao credor o bem da vida que a decisão judicial lhe atribuiu"11.

A gama de possibilidades que advém desse modelo amplo de coerção tem por objetivo a efetivação dos créditos executados, e age de forma a impedir que as execuções se protraiam no tempo sem solução, além de evitar que o devedor faça do processo um meio para evitar o pagamento de sua dívida.

Reconhecer que o crédito e a ação são direitos distintos, e que o poder de pôr as mãos sobre o patrimônio do devedor é uma prerrogativa do Estado dotada de caráter público, significa simplesmente dar a cada um o seu e colocar ordem numa série de conceitos indevidamente $\operatorname{confusos}^{12}$. Daí decorre que a efetividade provém dessa ação (execução) que busca conceder o crédito ao seu titular de forma específica.

Consequentemente, a responsabilidade, ao invés de ser elemento da relação jurídica obrigacional, é vínculo de direito público processual, consistente na sujeição dos bens do devedor, destinados a satisfazer o credor que não recebeu a prestação devida. Essa transferência patrimonial ocorre por meio da realização da sanção por parte do órgão judiciário $^{13}$, para dar verdadeira efetividade ao processo e, mais restritamente, ao processo de execução.

\section{A atual concepção da efetividade a partir do devido processo legal e da menor onerosidade}

\footnotetext{
${ }^{11}$ STJ, REsp 1.733.697/RS, Terceira Turma, Rel. Min. Nancy Andrighi, j. 11.12.2018, DJe 13.12.2018.

${ }^{12}$ LIEBMAN, Enrico Tullio. Processo de Execução, $3^{\text {a }}$ edição. São Paulo: Saraiva, 1968, p. 32.

${ }^{13}$ Ibidem.
} 
No processo de execução, a função do magistrado é prevalentemente prática e material. Ao contrário do processo de cognição, as partes não estão em equilíbrio ${ }^{14}$ e o contraditório assume contornos diversos, em alguns casos até limitado, por exemplo, quando a colaboração do executado for necessária para garantir que não haja excesso no cumprimento da sua condenação e para que a lei seja respeitada.

Se, de um lado, o credor, em busca da satisfação de seu direito material, dispõe do instrumento consubstanciado no processo de execução, que o coloca em privilegiada posição, não pode ser olvidado que, de outro, deve ser resguardado ao devedor o devido processo legal, em toda a sua dimensão, com observância da garantia de um amplo acesso à justiça $^{15}$ e de uma ampla defesa.

É claro que sempre se busca a efetividade do processo e da execução como corolário, mas os fins não justificam os meios: não pode afastar os litigantes do devido processo legal e das garantias de defesa, inerentes a todos os tipos de procedimento judicial. Nesse sentido, a preocupação de Egas Moniz de Aragão, ao estabelecer que a efetividade da execução não pode nem deve atingir as garantias constitucionais dos jurisdicionados, seja no que concerne à invocação do Poder Judiciário, seja no que diz com o devido processo legal, ou com o tratamento a dispensar aos litigantes. ${ }^{16}$

A própria exigência de formação de um título executivo é uma decorrência da necessidade de observância do devido processo legal, funcionando para o indivíduo como uma garantia de que só haverá a invasão de sua esfera de liberdade pessoal e patrimonial pelo Estado-juiz nas hipóteses rigorosamente previstas em lei ${ }^{17}$.

Desse modo, vencido o ciclo da interferência da função estatal na vida dos direitos e com vistas a obter o mesmo resultado jurídico material (efetividade) que o adimplemento voluntário teria produzido, conclui-se que é só essa verificação objetiva que interessa: se o

${ }^{14}$ Ibidem (...). Ob. cit., p. 38. Tomando como base a Constituição de 1988, essa assertiva de Liebman perde espaço ao se observar que ela assegura, em todos os processos, o contraditório e a ampla defesa, na mesma medida para ambas as partes.

15 TUCCI, José Rogério Cruz. Tutela Processual do Direito do executado (20 anos de vigência do CPC) in O Processo de Execução: estudos em homenagem ao Professor Alcides de Mendonça Lima. Porto Alegre: S.A. Fabris, 1995, p. 240.

${ }^{16}$ ARAGÃO, E. D. Moniz de. Efetividade do processo de execução. In: O Processo de Execução - Estudos em homenagem ao professor Alcides de Mendonça Lima. Porto Alegre: S. A Fabris, 1995, p. 135.

${ }^{17}$ GRECO, Leonardo. A crise do processo de execução. In: GRECO, L. Estudos de direito processual. Campos dos Goytacazes: Ed. Faculdade de Direito de Campos, 2005. 
instrumento destinado à atuação da vontade da lei cumpriu sua missão ${ }^{18}$, e, portanto, foi efetivo.

A efetividade da execução deve ser analisada, ainda, sob o prisma da menor onerosidade. Dispõe o art. 805 do Código de Processo Civil que, "quando por vários meios o exequente puder promover a execução, o juiz mandará que se faça pelo modo menos gravoso para o executado", no que se trata de uma positivação do princípio da menor onerosidade.

A partir desse enquadramento normativo, pode-se afirmar que a execução, muito embora pensada de forma a atender primordialmente os interesses do credor - e por isso a ideia de efetividade -, não deixa de ter uma baliza que assegure proteção ao devedor, impedindo que seja realizada a qualquer custo.

Nesse quadro, situa-se o princípio da menor onerosidade, em que os atos do procedimento executivo precisam ser pensados em benefício do credor, mas sem onerar excessivamente o devedor, causando-lhe, assim, menor prejuízo ${ }^{19}$.

Como afirma o Superior Tribunal de Justiça, o princípio em debate "expressa típica regra de sobredireito, cuja função é a de orientar a aplicação das demais normas do processo de execução, a fim de evitar a prática de atos executivos desnecessariamente onerosos ao executado" 20 .

Identificam-se, portanto, dispositivos que equilibram a execução, com a imposição de limites à tutela executiva, evidenciando a presença marcante do princípio da menor onerosidade, não apenas de modo genérico, mas com aplicação direcionada às hipóteses concretas.

Destarte, a execução não é um instrumento de exercício de vingança privada, não sendo justificável que o executado sofra mais do que o estritamente necessário na busca da satisfação do direito do exequente.

\footnotetext{
${ }^{18}$ DINAMARCO, Cândido Rangel. Ob. cit., p. 112.

${ }^{19}$ Como exemplos da irradiação do princípio da menor onerosidade, vale observar o artigo 835, do CPC/15, que dispõe sobre a ordem de preferência a ser obedecida com relação aos bens penhoráveis; o parágrafo único do art. 891, que não autoriza arrematação em valor inferior a cinquenta por cento do valor da avaliação, quando não se houver fixado preço mínimo; o art. 916, que autoriza o pagamento parcelado nas execuções por quantia.

${ }^{20}$ REsp 673.869/PR, Rel. Ministro TEORI ALBINO ZAVASCKI, PRIMEIRA TURMA, DJ 11/02/2008.
} 
Como bem registra Gilberto Gomes Bruschi, "não pode a execução ser utilizada para causar ruína, a fome e o desabrigo do devedor e de sua família, gerando situações incompatíveis com a dignidade da pessoa humana"21.

Com efeito, se há uma preponderância na organização da execução em favor do exequente, é também necessário que haja regras de contenção que evitem excessiva invasão na esfera de interesses do executado.

A ideia de menor onerosidade, assim, se deve também a razões humanitárias, de equidade, em respeito a valores fundamentais do ser humano, como a vida, saúde e moradia, repelindo-se atos de abuso ou o mero capricho por parte do credor $^{22}$.

Na linha do que aduz Alexandre Minatti, “contrapõe-se ao princípio do resultado (ou da máxima efetividade), o princípio da menor onerosidade possível, a ditar que a atividade executiva não pode afligir o executado para além do necessário à satisfação do exequente"23.

Também o STJ já afirmou que "o princípio da menor onerosidade não é absoluto, devendo ser observado em consonância com o princípio da efetividade da execução, preservando-se o interesse do credor" 24 .

Ademais, havendo conflitos entre princípios, é frequente o trunfo do princípio da menor onerosidade para limitar as escolhas do exequente e impedir potencial abuso de direito, cabendo ao juiz, no caso concreto, encontrar um meio termo que evite sacrifícios exagerados tanto ao exequente quanto ao executado.

Por outro lado, é importante deixar claro que o princípio em estudo, como outro qualquer, jamais pode servir de pretexto para encobrir ilegalidades, para proteger o devedor inescrupuloso, que se vale do processo para ludibriar o credor em sua a boa-fé ou postergar irregularmente o cumprimento de sua obrigação ${ }^{25}$.

O princípio da menor onerosidade cede, ainda, em detrimento de outros de maior envergadura, como o princípio constitucional da dignidade da pessoa humana, em consonância com a proteção ao menor que deve circundar toda sociedade. Nesse sentido, o

\footnotetext{
${ }^{21}$ BRUSCHI, Gilberto Gomes. Recuperação de crédito [livro eletrônico], 2. ed. São Paulo: Thomson Reuters Brasil, 2019.

${ }^{22}$ SHIMURA, Sérgio. O princípio da menor gravosidade ao executado. In: BRUSCHI, G. G.; SHIMURA, S. (Coords.). Execução civil e cumprimento de sentença. São Paulo: Método, v. II, 2007.

${ }^{23}$ MINATTI, Alexandre. Defesa do executado. São Paulo: Editora Revista dos Tribunais, 2017, p. 41.

${ }^{24}$ AgInt no AREsp 1563740/RJ, Rel. Ministro RAUL ARAÚJO, QUARTA TURMA, DJe 25/05/2020.

${ }^{25}$ SHIMURA, Sérgio. Ob. Cit.
} 
STJ já decidiu que "em execução de alimentos não incide o princípio da menor onerosidade do devedor, que cede espaço à regra da máxima efetividade que deve tutelar o interesse do credor em situações como tais" 26 .

Nessa linha, o princípio da menor onerosidade não pode ser confundido com privilégios e proteção exacerbada ao executado, até porque, como mencionamos anteriormente, a execução deve servir primordialmente à tutela dos direitos e interesses do exequente ${ }^{27}$.

Assim, aquele que alega ofensa à menor onerosidade, obrigatoriamente, deve demonstrar a desnecessidade do meio executivo utilizado e a existência de outras formas mais úteis (menos gravosas) à satisfação da dívida.

Podemos concluir que, embora haja sólidos argumentos favoráveis à definição da menor onerosidade como princípio jurídico, não se pode deixar de lado que o art. 805 do CPC/15 também pode ser considerado uma regra que oferta vantagem pontual ao executado no que tange à adoção das técnicas executórias desfavoráveis, quando existentes outras igualmente idôneas.

\section{A desjudicialização da execução como forma de efetividade do processo executivo}

Um dos maiores desafios do Poder Judiciário está relacionado, justamente, ao enfrentamento da baixa efetividade no resultado dos processos em fase de execução, que correspondiam, ao final do ano de 2019, a mais da metade dos processos em tramitação, segundo o Relatório Justiça em Números 2020 do $\mathrm{CNJ}^{28}$.

Os dados estatísticos apontam percentual relevante de casos nos quais se esgotaram os meios previstos em lei para a localização de bens do devedor, frustrando a satisfação do crédito já reconhecido em título executivo. Nesse sentido, é preciso o diagnóstico de Rubens Curado para quem o cumprimento de sentença/execução é, de longe, o maior problema do Judiciário, não apenas em razão da quantidade maior de acervo, mas sobretudo porque seu

\footnotetext{
${ }^{26}$ REsp 1301467/MS, Rel. Ministro LUIS FELIPE SALOMÃO, QUARTA TURMA, DJe 27/05/2016.

${ }^{27}$ CAMARGO, Daniel Marques de. O novo Código de Processo Civil e os princípios da execução civil. In: ALVIM, A. et al (org.). Execução Civil e temas afins - do CPC/73 ao novo CPC. São Paulo: Revista dos Tribunais, 2014.

${ }^{28}$ BRASIL. Conselho Nacional de Justiça, Justiça em Números, 2020. p. 150.
} 
índice de vazão é bem menor do que na fase de conhecimento. E arremata: "as execuções iniciam, mas não terminam" 29

Uma das propostas para o enfrentamento desse problema é o Projeto de Lei 6.204/19 que, se aprovado, modificará sobremaneira o cenário da jurisdição nacional. Trata o referido Projeto de Lei da desjudicialização das execuções civis que, em poucas palavras, pode ser compreendida como a transferência da competência do Estado-juiz, por delegação, aos tabeliães de protesto - à semelhança do que ocorre em Portugal $^{30}$.

Tal iniciativa, se acolhida, representaria uma radical ruptura do nosso tradicional sistema executivo que, como regra ${ }^{31}$, outorga ao juiz, privativamente, o poder de determinar a prática de atos executivos (art. 782 do CPC/2015). Trata-se de um fenômeno baseado na ideia de se retirar do Poder Judiciário a atribuição total ou parcial de processar as execuções de título judicial e extrajudicial, delegando a entes privados essa atribuição.

Trata-se, em verdade, de um fenômeno que não alcança apenas a execução, mas, sim, todo e qualquer ato ou processo judicial que se pretenda excluir da apreciação do Poder Judiciário, conferindo-lhe a mesma força que teria se permanecesse como de competência daquele Poder.

Mas não é só. Significa a possibilidade de solução de conflitos de interesse sem a prestação jurisdicional, como se fez no Brasil com a Lei no 11.441/2007, que estabeleceu a desjudicialização dos divórcios e inventários ${ }^{32}$.

Nesse sentido, atualmente, os atos executivos são atos jurisdicionais, sendo ordenados pelo juiz, razão pela qual, ao estabelecer que os atos executivos serão determinados pelo magistrado, o texto normativo enuncia que a execução forçada é ato do Estado, submetido ao seu império, que, aliás, constitui um monopólio seu ${ }^{33}$. Destarte, a

\footnotetext{
${ }^{29}$ CURADO, Rubens. O problema está na execução. Jota.info, 28 ago. 2015. Disponível em: https://www.jota.info/paywall?redirect_to=//www.jota.info/opiniao-e-analise/artigos/o-problema-esta-naexecucao-21082015. Acesso em: 25 nov. 2020.

${ }^{30}$ Em Portugal, por exemplo, a atividade executiva é da competência de agentes de execução particulares, sob delegação do Poder Judiciário. Para um bom panorama da desjudicialização pela Europa, vale a leitura do seguinte trabalho: FARIA, Márcio Carvalho. Primeiras impressões sobre o Projeto de Lei 6.204/2019: críticas e sugestões acerca da tentativa de se desjudicializar a execução civil brasileira (parte um). Revista de Processo, vol. 313, mar. 2021, p. 393/414.

${ }^{31}$ Há exceções previstas no próprio CPC/2015, como os arts. 255 e 782, §1 $1^{\circ}$, que permitem a prática de atos executivos pelos oficiais de justiça em comarcas contíguas ou regiões metropolitanas, sendo-lhes permitido efetuar citações, intimações, notificações, penhoras e quaisquer outros atos executivos.

${ }^{32}$ RIBEIRO, Diógenes V. Hassan. Judicialização e desjudicialização: Entre a deficiência do legislativo e a insuficiência do judiciário. Revista de Informação Legislativa, Ano 50 Número 199 jul./set. 2013, p. 30.

${ }^{33}$ CUNHA, L. C. D. et al (org.). Comentários ao Código de Processo Civil. 2a ${ }^{\text {a }}$ ed. São Paulo: Saraiva, 2017.
} 
transferência dessa atividade executiva, ao menos em parte, para um órgão privado constitui uma das facetas da desjudicialização.

No direito comparado, vê-se com relativa naturalidade a transferência das funções de localização de bens, efetivação da penhora, avaliação e arrematação a cargo de agentes distintos da figura do juiz, que teria competência para, mediante provocação, rever ou anular tais atos.

É o que ocorre, cada qual com suas peculiaridades, nos sistemas executivos de França, Suécia, Espanha, Portugal, Romênia, Letônia, Lituânia, República Checa e Eslováquia $^{34}$. Na Itália e na Alemanha, a execução principia com atos do oficial de justiça ou executor judicial, interferindo o juiz apenas depois de consumada a agressão ao patrimônio do executado. Nos Estados Unidos, a execução se inicia por ordem do juiz, mas os atos executórios são atribuídos a terceiros encarregados que operam na qualidade de "officers of the Court"35.

A desjudicialização da execução civil, no entanto, ainda não vingou em solo brasileiro. Por aqui, alguns atos executivos já não mais precisam do Poder Judiciário, mas ainda são poucos e tímidos. Ex: alienação do bem penhorado por iniciativa particular (art. 880 do CPC/15), o protesto do título judicial (art. 517 do CPC/15) e a execução extrajudicial de cédula hipotecária (Decreto-lei 70/66).

Outros atos executivos são realizados pelo Judiciário, mas não pelo Juiz. Ex: avaliação do bem penhorado, arresto de bens e leilão dos bens constritos. Autoriza-se, também, excepcionalmente, a prática de atos executivos por oficiais de justiça em comarcas contíguas ao juízo e regiões metropolitanas (arts. 255 e 782, § $1^{\circ}$, do CPC), sendo-lhes permitido efetuar "citações, intimações, notificações, penhoras e quaisquer outros atos executivos".

Segundo dispõe o Projeto de Lei da desjudicialização, os tabeliães de protesto serão chamados de agentes da execução, já afeitos aos temas dos títulos de créditos, além

p. 1049.

34 BECKER, Rodrigo; PEIXOTO, Marco Aurélio. Desjudicialização da execução fiscal - promessa ou realidade?. Jota.info, 06 dez. 2018. Disponível em: https://www.jota.info/opiniao-e-analise/colunas/colunacpc-nos-tribunais/desjudicializacao-da-execucao-fiscal-promessa-ou-realidade-06122018. Acesso em: 20 nov. 2020.

35 TARUFFO, Michele. A atuação executiva dos direitos: perfis comparatísticos. Revista de processo, v. 15, n. 59, p. 72-97, jul./set. 1990. Disponível em: https://bdjur.stj.jus.br/jspui/handle/2011/131792. Acesso em: 15 jan. 2021. 
detentores de uma infraestrutura compatível e adequada $^{36}$ aos atos e procedimentos executivos. Haveria, assim, a descaracterização de parte da atividade executiva como jurisdicional.

É exatamente a ideia de retirar do Poder Judiciário brasileiro a atribuição para a execução de títulos judiciais e extrajudiciais e delegá-la aos tabelionatos de protestos, que funcionariam como agentes de execução, com diversas competências, promovendo uma maior efetividade da atividade executiva, de modo a resolver o problema instaurado entre credor e devedor.

Evidentemente, como bem pontua Flavia Hill, tal sistema deverá zelar pela observância do devido processo legal extrajudicial, significando que os atos executivos praticados pelos tabeliães de protestos deverão obedecer aos princípios do contraditório, da ampla defesa, da duração razoável do processo, da instrumentalidade das formas, da imparcialidade do agente da execução, entre outros ${ }^{37}$.

Quanto à constitucionalidade, parece-nos que a proposta de desjudicialização de atos executivos não se mostra materialmente incompatível com a Constituição Federal, na medida em que os atos executivos não necessariamente estão inseridos em cláusula de reserva de jurisdição.

Isso porque não há qualquer dispositivo constitucional que, de modo expresso, imponha a prática desses atos exclusivamente aos juízes de direito. $\mathrm{O}$ art. $5^{\circ}$, inciso LIV, da Constituição determina a observância do devido processo legal quanto à privação da liberdade e de bens, sendo que tal garantia deve ter incidência em qualquer processo, judicial ou extrajudicial, que possa causar prejuízo àqueles que dele participem ${ }^{38}$. Desse ponto, o projeto de lei não se distancia porque estabelece que todo o procedimento em cartório deve ser pautado pela garantia do referido devido processo legal.

36 Conforme destaca Joel Dias Figueira Júnior, “o número de juízes de primeiro grau e varas com competência (específica ou cumulativa) para execução cível é muitíssimo inferior ao número de serventuários e serventias extrajudiciais distribuídas por todo o território nacional." (In Desjudicialização da execução civil: As razões contidas no PL 6.204/19. Migalhas, 07 jul. 2020. Disponível em: https://migalhas.uol.com.br/depeso/330308/desjudicializacao-da-execucao-civil. Acesso em: 15 jan. 2021.)

${ }^{37}$ HILL, Flávia Pereira. Desjudicialização da execução civil: reflexões sobre o Projeto de Lei no 6.204/2019. Revista Eletrônica de Direito Processual - REDP, Rio de Janeiro, v. 21, n. 3, p. 164-205, set. a dez. 2020.

${ }^{38}$ PEIXOTO, Renata Cortez Vieira. O Projeto de Lei no 6.204/2019 e a Desjudicialização da Execução Civil: Adequação da Atribuição de Agentes de Execução aos Tabeliães de Protestos. Revista ANNEP de Direito Processual, vol. $1, \mathrm{n}^{\circ} 2,2020$, p. 90. 
Ademais, diversamente do que ocorre na fase de conhecimento, o processo executivo não costuma exigir do magistrado, como regra, grande esforço intelectual, sendo atividade preponderantemente prática $^{39}$, caracterizada pela determinação de atos, muitas vezes meramente cartorários ou burocráticos, voltados à satisfação da obrigação.

Deve-se ter claro, por oportuno, que a inafastabilidade da Jurisdição também estaria protegida, na medida em que o juiz ainda atuaria para solucionar as controvérsias surgidas no curso da execução, providências coercitivas, além de eventuais embargos à execução (art. 18 do PL 6.204/2019).

Desse modo, por exemplo, as consultas do agente da execução sobre questões relacionadas ao título exequendo e ao procedimento executivo (art. 20 do PL), bem como as suscitações de dúvida apresentadas pelos interessados relativamente às decisões dos agentes da execução (art. 21 do PL) devem, de acordo com o projeto de lei, ser dirigidas ao Poder Judiciário.

O Judiciário, assim, serviria apenas para realizar uma espécie de controle da execução desjudicializada. Para Tarzia, o juiz da execução deveria funcionar como um "juiz de incidentes", intervindo apenas em questões de relevância jurídica, resolvendo controvérsias surgidas no curso da execução, naquelas em que sua função não pode ser eliminada, transformando-se em um juiz de questões que surjam durante a execução, ou durante os embargos à execução, do devedor ou de terceiros ${ }^{40}$.

Por tal razão é que a busca pela efetividade do processo, e por consequência, da execução, deve se pautar por todos os meios jurídicos e legalmente cabíveis, sendo a desjudicialização um fenômeno que, certamente, contribuirá, e muito, para esse desiderato.

\section{A promessa de efetividade da execução a partir das soluções tecnológicas}

Em paralelo à discussão da desjudicialização da execução cível, tratada no tópico anterior, pululam nos tribunais brasileiros e no Conselho Nacional de Justiça diversas

\footnotetext{
${ }^{39}$ GRECO, Leonardo. A crise do processo de execução. In: GRECO, L. Estudos de direito processual. Campos dos Goytacazes: Ed. Faculdade de Direito de Campos, 2005.

${ }^{40}$ TARZIA, Giuseppe. Problemas atuais da execução forçada. Revista de processo, São Paulo, v. 23, n. 90, p. 68-84, abr./jun. 1998. Disponível em: http://bdjur.tjdft.jus.br/xmlui/handle/tjdft/36537. Acesso em: 15 dez. 2020.
} 
iniciativas voltadas ao desenvolvimento de ferramentas tecnológicas, visando o aprimoramento da gestão da tramitação processual.

As soluções de inteligência artificial se apresentam como instrumentos de realização de uma gestão eficiente do acervo processual dos tribunais pátrios, com aptidão de substituir a ação humana em tarefas repetitivas ou apresentar recomendações de atuação para determinada rotina, com otimização da tramitação processual e automação do fluxo de trabalho.

Naquilo que concerne ao objeto do presente trabalho, vê-se a paulatina implementação de soluções tecnológicas com potencial de grande impacto na efetividade da execução, capazes de conferir maior agilidade, racionalidade e eficácia aos atos voltados à satisfação do título executivo pelo exequente.

Podemos apontar, por exemplo, o aprimoramento do sistema de "penhora on-line", prevista no art. 854 do CPC/2015, com a recente substituição do BacenJud pelo SisbaJud Sistema de Busca de Ativos do Poder Judiciário.

O SisbaJud, desenvolvido pelo CNJ em parceria com o Banco Central e a Procuradoria da Fazenda Nacional, tem objetivo de dar maior celeridade no cumprimento das decisões judiciais e, consequentemente, na efetividade das execuções.

Entre as novas ferramentas, o sistema possibilita o bloqueio célere não só de valores em conta corrente, mas também de ativos mobiliários, como títulos de renda fixa, ações, fundos de rendimento e demais opções de investimentos autorizadas pela Comissão de Valores Mobiliários. No caso de pessoas jurídicas, o sistema consegue localizar, pelos primeiros dígitos do CNPJ, as filiais da empresa matriz, mitigando as possibilidades de fraude à execução.

Além disso, automatiza-se os trâmites administrativos para cumprimento das requisições judiciais de informações financeiras (afastamento de sigilo bancário) e das ordens de bloqueio de valores. No antigo BacenJud, tais rotinas levariam semanas ou até meses para cumprimento ${ }^{41}$.

41 Notícias CNJ. "SisbaJud melhora efetividade da execução judicial", disponível em: https://www.cnj.jus.br/sisbajud-melhorar-efetividade-da-execucao-judicial/. Acesso em: 15 dez. 2020. 
Permite, também, o envio eletrônico de informações sobre extratos em conta corrente, fatura de cartão de crédito e operações de câmbio, contribuindo de forma significativa para a localização de bens do executado.

O SisbaJud foi desenvolvido sem olvidar do princípio da menor onerosidade, analisado acima, com a existência de campo para indicação do limite do valor que se pretende bloquear. Vale lembrar que, nos termos do art. $854, \S 3^{\circ}$, do $\mathrm{CPC} / 2015$, é ônus do executado demonstrar que as quantias tornadas indisponíveis eram impenhoráveis, ou que houve excesso de constrição dos ativos financeiros, o que é suscitado e decidido a posteriori, isto é, após a realização do bloqueio.

Por sua vez, o Renajud também é um sistema on-line de restrição judicial dirigido aos veículos, criado por acordo de cooperação técnica ${ }^{42}$ entre o Conselho Nacional de Justiça, o Ministério das Cidades e o Ministério da Justiça, que interliga o Judiciário ao Departamento Nacional de Trânsito (Denatran), possibilitando consultas e o envio, em tempo real, de ordens judiciais eletrônicas de restrição - inclusive registro de penhora - e de retirada de restrição de veículos automotores na Base Índice Nacional do Registro Nacional de Veículos Automotores - RENAVAM ${ }^{43}$.

Outras iniciativas promissoras são vistas em diversos Tribunais pelo País e demonstram coma a tecnologia tem auxiliado na busca pela efetividade do processo executivo.

No Rio Grande do Norte, o Tribunal de Justiça local desenvolveu o sistema Poti, que conta com a inteligência artificial para realizar automaticamente a busca e bloqueio de valores em contas bancárias. Caso frustrada a localização de bens, o Poti pode ser programado para realizar novas tentativas em períodos consecutivos, de 15, 30 ou 60 dias. Tais tarefas, quando realizadas por serventuários da justiça, levavam semanas ou meses para ser cumpridas.

Ferramenta similar é encontrada no Tribunal de Justiça do Paraná, com o PIAA Projeto de Inteligência Artificial e Automação, que também possibilita a automação de busca de endereços, análises de saldos bancários e bloqueio de valores.

\footnotetext{
${ }^{42}$ Assinado em 2006 pela Presidente do CNJ, à época, Min. Ellen Gracie, e os Ministros Márcio Thomaz Bastos, da Justiça, e Márcio Fortes, das Cidades.

${ }^{43}$ Art. $2^{\circ}$ do anexo do Regulamento de operacionalização do sistema.
} 
Para além do aprimoramento das ferramentas de localização de bens do executado, apontamos, sem maiores detalhamentos, a existência de outras inovações tecnológicas, com utilização ou não de inteligência artificial.

Entre as tarefas realizadas por tais sistemas tecnológicos, destacam-se atividades como: identificar classes processuais e assuntos; identificar demandas repetitivas; identificar a prática de litigiosidade predatória; triar e agrupar processos semelhantes; apresentar sugestão de minutas de despacho ou decisão; realizar análise de prescrição, todas relacionadas à otimização de rotinas administrativas e processuais. ${ }^{44}$

Para evitar o desenvolvimento paralelo de soluções tecnológicas semelhantes, o CNJ, em parceria com o TJRO, desenvolveu o SINAPSES, plataforma que possibilita o compartilhamento de modelos de inteligência artificial e algoritmos em repositório comum, acessível pelos diversos tribunais brasileiros.

Tais iniciativas, se bem-sucedidas, prometem superar os obstáculos que impedem a entrega do bem da vida ao exequente, fazendo com que o procedimento seja, de fato, efetivo, reduzindo o número de execuções em juízo, e solucionando conflitos executivos que hoje se perdem nos Tribunais brasileiros.

\section{Conclusão}

O processo de execução deve ser capaz de promover, de forma eficiente e adequada, a realização do direito material das partes, pelo adimplemento da obrigação contida no título executivo. A efetividade do processo deve ser compreendida não pelo mero reconhecimento do direito material, mas por sua concretização e realização no aspecto prático, isto é, "sensíveis no plano exterior do processo ${ }^{45 "}$ ".

Nesse sentido, o processo civil deve superar os estigmas da inefetividade, dispendiosidade e morosidade. Com efeito, a existência de execuções que se demonstram

\footnotetext{
${ }^{44}$ Pesquisa realizada na FGV identificou, no ano de 2020, pelo menos 72 projetos de inteligência artificial nos tribunais brasileiros, em diferentes fases de implementação. "Judiciário brasileiro tem ao menos 72 projetos de inteligência artificial nos tribunais", disponível em: https://www.jota.info/coberturas-especiais/inova-eacao/judiciario-brasileiro-tem-ao-menos-72-projetos-de-inteligencia-artificial-nos-tribunais09072020?amp=1. Acesso em: 15 jan. 2021.

${ }^{45}$ BUENO. Cassio Scarpinella. Curso sistematizado de direito processual civil: teoria geral do direito processual civil. 8a . ed., v.1. São Paulo: Saraiva, 2014.
} 
eternamente inoperantes não se mostra interessante para a ordem jurídica, visto que põem em risco a confiança e a segurança do sistema judicial.

A crise de efetividade da prestação jurisdicional promove a insatisfação dos jurisdicionados e um sentimento de descrença no próprio Poder Judiciário, o que nos leva à reflexão sobre as alternativas de aperfeiçoamento do nosso sistema executivo.

Evidentemente, a prestação de uma tutela jurisdicional adequada e eficiente exige uma correspondente capacidade material e humana do Poder Judiciário para fazer frente à quantidade de processos em tramitação, levando-se em conta a complexidade natural própria dos processos judiciais.

Não se pretendeu, aqui, oferecer um caminho único ou uma solução definitiva para a crise de efetividade da execução, mas, sem dúvidas, o enfrentamento do problema deve perpassar por um debate maduro da proposta de desjudicialização das execuções e pelo aprimoramento dos institutos jurídicos-processuais diante das novas ferramentas tecnológicas, como a automatização do sistema de "penhora online" e a utilização de inteligência artificial para auxiliar na busca e localização de ativos, analisados no decorrer deste artigo.

\section{REFERÊNCIAS}

ARAGÃO, E. D. M. D. Efetividade do processo de execução. In: ANTUNES, Apio Cláudio de Lima et al (org.). O processo de execução: estudos em homenagem ao Professor Alcides de Mendonça Lima. Porto Alegre: Fabris, 1995.

BECKER, R.; PEIXOTO, M. A. Desjudicialização da execução fiscal - promessa ou realidade?. Jota.info, 06 dez. 2018. Disponível em: https://www.jota.info/opiniao-eanalise/colunas/coluna-cpc-nos-tribunais/desjudicializacao-da-execucao-fiscalpromessa-ou-realidade-06122018. Acesso em: 20 nov. 2020.

BRUSCHI, G. G. Recuperação de crédito. 2a . ed. São Paulo: Thomson Reuters Brasil, 2019.

BUENO, C. S. Curso sistematizado de direito processual civil: teoria geral do direito processual civil. 8a . Ed, v. I. São Paulo: Saraiva, 2014. 
CAMARA, A. F. Execução civil e temas afins do CPC/1973 ao novo CPC: estudos em homenagem ao professor Araken de Assis. São Paulo: Revista dos Tribunais, 2014.

CAMARGO, D. M. D. O novo Código de Processo Civil e os princípios da execução civil. In: ALVIM, A. et al (org.). Execução Civil e temas afins - do CPC/73 ao novo CPC. São Paulo: Revista dos Tribunais, 2014.

CUNHA, L. C. D. et al (org.). Comentários ao Código de Processo Civil. $2^{\text {a }}$. ed. São Paulo: Saraiva, 2017.

CURADO, R. O problema está na execução. Jota.info, 28 ago. 2015. Disponível em: https://www.jota.info/paywall?redirect_to=//www.jota.info/opiniao-eanalise/artigos/o-problema-esta-na-execucao-21082015. Acesso em: 25 nov. 2020.

DINAMARCO, C. R. Execução Civil. 5a . ed. São Paulo: Malheiros editores, 1997.

FARIA, M. C. Primeiras impressões sobre o Projeto de Lei 6.204/2019: críticas e sugestões acerca da tentativa de se desjudicializar a execução civil brasileira (parte um). Revista de Processo. São Paulo: Revista dos Tribunais, vol. 46, n. 313, Mar/2021.

FIGUEIRA JÚNIOR, J. D. Desjudicialização da execução civil: As razões contidas no PL 6.204/19. Migalhas, 07 jul. 2020. Disponível em: https://migalhas.uol.com.br/depeso/330308/desjudicializacao-da-execucao-civil. Acesso em: 15 jan. 2021.

FUX, L. A reforma do processo civil: comentários e análise crítica da reforma infraconstitucional do Poder Judiciário e da Reforma do CPC. 2a . ed. Niterói: Impetus, 2008.

GRECO, L. A crise do processo de execução. In: GRECO, L. Estudos de direito processual. Campos dos Goytacazes: Ed. Faculdade de Direito de Campos, 2005.

HILL, F. P. Desjudicialização da execução civil: reflexões sobre o Projeto de Lei ${ }^{\circ}$ 6.204/2019. Revista Eletrônica de Direito Processual - REDP, Rio de Janeiro, v. 21, n. 3, p. 164-205, set. a dez. 2020. Disponível: https://www.epublicacoes.uerj.br/index.php/redp/article/view/54202/34876. Acesso em: 20 jan. 2021.

LIEBMAN, E. T. Processo de Execução. 3ª . ed. São Paulo: Saraiva, 1968.

MARINONI, L. G.; ARENHART, S. C.; MITIDIERO, D. Manual de processo civil. $5^{\mathrm{a}}$. ed. São Paulo: Thomson Reuters Brasil, 2020. 
MEDINA, J. M. G. A era da Inteligência Artificial: As máquinas poderão tomar decisões judiciais? Revista dos Tribunais, São Paulo, v. 109, n. 1020, out. 2020.

MINATTI, A. Defesa do executado. São Paulo: Editora Revista dos Tribunais, 2017.

PEIXOTO, R. C. V. O Projeto de Lei n ${ }^{\circ}$ 6.204/2019 e a Desjudicialização da Execução Civil: Adequação da Atribuição de Agentes de Execução aos Tabeliães de Protestos. Revista ANNEP de Direito Processual, Vol. 1, nº 2, 2020

PINHO, H. D. B. D. Manual de direito processual civil contemporâneo. $2^{\text {a }}$. ed. São Paulo: Saraiva, 2020.

RIBEIRO, D. V. H. Judicialização e desjudicialização: Entre a deficiência do legislativo e a insuficiência do judiciário. Revista de Informação Legislativa, Ano 50 Número 199 jul./set. 2013

RIBEIRO, F. P. Desjudicialização da Execução Civil. 2ª ed. Curitiba: Juruá, 2019.

RICHTER, B. M. P.; SILVA, N. D. O controle de convencionalidade como limite para a discricionariedade do juiz na execução: análise das decisões recentes que têm aplicado o artigo 139, IV, do novo Código de Processo Civil. In: MAIA, M. L.; LIRA; Y. (org.). Controle de Convencionalidade - Temas aprofundados. Salvador: Juspodivm, 2018.

SHIMURA, S. O princípio da menor gravosidade ao executado. In: BRUSCHI, G. G.; SHIMURA, S. (Coords.). Execução civil e cumprimento de sentença. São Paulo: Método, v. II, 2007.

TARUFFO, M. A atuação executiva dos direitos: perfis comparatísticos. Revista de processo, v. 15, n. 59, p. 72-97, jul./set. 1990. Disponível em: https://bdjur.stj.jus.br/jspui/handle/2011/131792. Acesso em: 15 jan. 2021.

TARZIA, G. Problemas atuais da execução forçada. Revista de processo, São Paulo, v. 23, n. 90, p. 68-84, abr./jun. 1998. Disponível em: http://bdjur.tjdft.jus.br/xmlui/handle/tjdft/36537. Acesso em: 15 dez. 2020. 